\title{
Antibacterial activity and stability of microencapsulated lemon grass essential oil in feeds for broiler chickens
}

\author{
Atividade antimicrobiana e estabilidade do óleo essencial de capim-limão \\ (Cymbopogon citratus) microencapsulados em ração para frangos de corte
}

\author{
ASSIS, Yhago Patrycky Antunes Souza ${ }^{1}$; ALMEIDA, Anna Christina de ${ }^{1 *}$; \\ NOGUEIRA, Wedson Carlos Lima ${ }^{1}$; SOUZA, Cintya Neves de ${ }^{1}$; GONÇALVES, \\ Samuel Ferreira ${ }^{1}$; SILVA, Flavio Emanuel Gomes ${ }^{1}$; SANTOS, Vanessa Kelly Ferreira \\ do Rosário ${ }^{1}$; MARTINS, Ernane Ronie ${ }^{1}$
}

\footnotetext{
${ }^{1}$ Universidade Federal de Minas Gerais, Campus de Montes Claros, Centro de Pesquisa em Ciências Agrárias, Montes Claros, Minas Gerais, Brasil.

*Endereço para correspondência: aca2006@ica.ufmg.br
}

\section{SUMMARY}

The antibacterial effect of microencapsulated lemon grass (Cymbopogon citratus) essential oil on strains of Escherichia coli (ATCC8739), Staphylococcus aureus (ATCC 6538) and Salmonella enterica subsp. enterica (ATCC 6017), and the stability of this oil in feeds for broiler chickens were evaluated. The Minimum Inhibitory Concentration (MIC) and Minimum Bactericidal Concentration (MBC) were determined by the macrodilution method, using the microencapsulated lemon grass essential oil at concentrations of $160 \mu \mathrm{L} \mathrm{mL}^{-1}, 80 \mu \mathrm{L} \mathrm{mL}^{-1}, 40 \mu \mathrm{L}$ $\mathrm{mL}^{-1}, 20 \mu \mathrm{L} \mathrm{mL} L^{-1}$, and $10 \mu \mathrm{L} \mathrm{mL}^{-1}$. The oil concentration of $80 \mu \mathrm{L} \mathrm{mL} \mathrm{m}^{-1}$ presented the best results against the three bacteria evaluated. Samples of $200 \mathrm{~g}$ of feed mixed with $120 \mu \mathrm{L} \mathrm{g}^{-1}$ of the microencapsulated lemon grass essential oil was stored to evaluate the oil stability. Feed without microencapsulated lemon grass essential oil was prepared as control. The oil remained active for seven days, with significant reduction of $S$. aureus (3.08 CFU), E. coli (3.01 CFU), and $S$. enterica (3.10 CFU). The microencapsulated lemon grass essential oil at concentration of $80 \mu \mathrm{L}$ $\mathrm{mL}^{-1}$ had antibacterial effect against the E. coli, $S$. enterica and $S$. aureus, and maintained stability of the feed for seven days, even with presence of organic matter, which is source of nutrients for pathogens.

Keywords: antimicrobial, Cymbopogon citratus, poultry farming, plant extract, multiphase

\section{RESUMO}

No trabalho foi avaliado o efeito antimicrobiano do óleo capim limão (Cymbopogon citratus) microencapsulado frente a cepas de Escherichia coli (ATCC8739), Staphylococcus aureus (ATCC 6538) e Salmonella enterica subsp. enterica (ATCC 6017), e a estabilidade do óleo em ração de frangos de corte. O teste de Concentração Inibitória Mínima (CIM) e Concentração Bactericida Mínima (CBM) do óleo essencial de capim-limão microencapsulado foi determinado pelo método de macrodiluição (tubo) utilizando as concentrações de $160 \mu \mathrm{L} / \mathrm{mL}, \quad 80 \mu \mathrm{L} / \mathrm{mL}$, $40 \mu \mathrm{L} / \mathrm{mL}, 20 \mu \mathrm{L} / \mathrm{mLe} 10 \mu \mathrm{L} / \mathrm{mL}$. A concentração do óleo de $80 \mu \mathrm{L} / \mathrm{mL}$ apresentou melhores resultados frente às três bactérias. Para a avaliação da estabilidade foram separados e armazenadas porções de $200 \mathrm{~g}$ de ração misturadas com o óleo essencial de capim limão na dosagem de $120 \mu \mathrm{L} / \mathrm{g}$ de ração, foram preparadas porções de ração sem a presença do óleo essencial para teste controle, os resultados mostraram que o óleo permaneceu ativo até sete dias, com redução significativa de 3,08 UFC para $S$. aureus, 3, 01 para $E$. coli e 3,10 S. entérica. Conclui-se que, óleo essencial de capimlimão microencapuslado tem atividade antibacteriana na concentração de $80 \mu \mathrm{L} / \mathrm{mL}$ frente à Escherichia coli, S. entérica e $S$. aureus e promove a estabilidade da ração no período de sete dias mesmo na presença da matéria orgânica que é fonte de nutrientes para patógenos.

Palavras-chaves: antimicrobiano, Cymbopogon citratus, avicultura, extratos vegetais, multifase 


\section{INTRODUCTION}

The emergence of resistant bacterial strains to antimicrobials that are responsible for pathologies in humans and animals generated a worldwide consensus on the need for a proper use of antimicrobials for therapeutic and prophylactic purposes and improvement of the performance of animal production, such as poultry farming ( GONZALES et al., 2012).

Many countries have implemented sanitary measures restricting the use of products from chickens raised with the use of antimicrobials as performance enhancers for humans. Thus, several researches have focused on molecules that can replace antimicrobials while maintaining the production level and lowering human health risks. These researches have been evaluating bioproducts, including plant extracts and essential oils (SILVA et al., 2011). Essential oils have high volatilization and reactivity, and changes in its color, taste, and texture can occur. Thus, their microencapsulation for using in feeds is an alternative to avoid these problems, since it increases its stability, controls the oil release, and protects the compounds from ultraviolet radiation, moisture, and contact with oxygen. Studies have reporting the maintenance of the pharmacological activity, and stability of microencapsulated essential oils (LEIMANN, 2008); thus, microencapsulation technologies have been used currently to include essential oils in feeds.

The essential oil of Cymbopogon citratus (DC.), Popularly known as Lemongrass, lemon balm, fennel-lemon balm, has antibacterial activity against poultry proven bacteria in in vitro assays (AZEVEDO et al., 2016).
The objective of this study was to evaluate the effect of using microencapsulated lemon grass essential oil in feeds for broiler chickens, and its antibacterial activity and stability in the presence of organic matter during the feed storage.

\section{MATERIAL AND METHODS}

According the gas chromatography-mass spectrometry analysis, the microencapsulated lemon grass essential oil used consisted mainly of citral (77.42\%) (AZEVEDO et al., 2016). Microencapsulation was performed using the coacervation method with edible polymers by the Croma Microencapsulados Company (São Paulo, Brazil). The microencapsulation thei oil was analyzed to verify the permanence of the compounds (AZEVEDO et al., 2016).

Standard strains of Escherichia coli (ATCC8739), Staphylococcus aureus (ATCC 6538) and Salmonella enterica subsp. enterica (ATCC 6017), were used to evaluate the antibacterial activity of the microencapsulated lemon grass essential oil. The inocula used in the tests were prepared in a $0.9 \%$ saline solution, obtaining between $10^{4}$ and $10^{5}$ Colonies Forming Units (CFU) $\mathrm{mL}^{-1}$, with 0.5 in the Marc Farland scale for each bacterium (CLSI, 2015).

The Minimum Inhibitory Concentration (MIC) was determined by the macrodilution method in a broth, according to CLSI (2015). The microencapsulated lemon grass essential oil concentrations $160 \mu \mathrm{L} \mathrm{mL}^{-1}, 80 \mu \mathrm{L}$ $\mathrm{mL}^{-1}, 40 \mu \mathrm{L} \mathrm{mL}^{-1}, 20 \mu \mathrm{L} \mathrm{mL}^{-1}$ and $10 \mu \mathrm{L}$ $\mathrm{mL}^{-1}$ were obtained in BHI broth, using Tween-80 as emulsifier. Microencapsulated lemon grass essential oil samples from each concentration 
were inoculated with $12.5 \mu \mathrm{L}$ of each standardized bacterial inoculum, and incubated at $37{ }^{\circ} \mathrm{C}$ for 24 hours. The control treatments consisted of a positive-growth control for each bacterium, a control for absence of contamination in the oils, and Tween- 80 as an innocuity control.

The MIC was defined as the lowest concentration of oil that is capable to inhibit bacterial growth, which was assessed visually by comparisons of turbidity with positive and negative controls(CLSI, 2015). The tests were performed in triplicates.

Samples of $12.5 \mu \mathrm{L}$ of the inoculum of each test tube with no bacterial growth in the MIC tests were evaluated by comparing them with the controls. They were inoculated in Plate Count Agar (PCA) in duplicates, incubated at $37{ }^{\circ} \mathrm{C}$ for 24 hours; then, the CFU were counted. The Minimum Bactericidal Concentration (MBC) was defined as the concentration of the oil that inhibit bacterial growth (CLSI, 2015).

A balanced feed for broiler chickens in the growth phase was prepared (ROSTAGNO et al., 2011) without adding performance enhancers. The feed was placed in an autoclave at 121 ${ }^{\circ} \mathrm{C}$ for 20 minutes to eliminate the microbial load and evaluate the absence of microbial contamination. Then, the autoclaved feed was inoculated in BHI broth and incubated at $37^{\circ} \mathrm{C}$ for 48 hours, in triplicate.

The antiseptic activity of the oil added to the feed was evaluated according to the recommendations of Brasil (2003), with adaptations. Test tubes containing $9 \mathrm{ml}$ of BHI, $1 \mathrm{~g}$ of sterile feed, and the microencapsulated lemon grass essential oil at different concentrations $800 \mu \mathrm{L} \mathrm{mL}^{-1}, 160 \mu \mathrm{L} \mathrm{mL}^{-1}, 80 \mu \mathrm{L} \mathrm{mL}^{-1}$, $40 \mu \mathrm{L} \mathrm{mL}^{-1}, 20 \mu \mathrm{L} \mathrm{mL}^{-1}$, and $10 \mu \mathrm{L} \mathrm{mL}^{-}$ 1 defined for MIC and MBC in this study, and $12.5 \mu \mathrm{L}$ of each bacterium were prepared. A positive control containing BHI, bacterial culture with feed, and a negative control containing BHI, feed, and microencapsulated lemon grass essential oil were also prepared.

The test tubes were incubated at $37{ }^{\circ} \mathrm{C}$ for $0,5,15,30$ and 60 minutes. An aliquot of $100 \mu \mathrm{L}$ was withdrawn from each tube, and inoculated into other tubes containing BHI and incubated at $37{ }^{\circ} \mathrm{C}$ for 96 hours. Subsequently, the turbidity of these materials was compared to the negative and positive controls. The tests were performed in triplicates. Trifenyltetrazolium chloride was added into the test tubes with no turbidity change to confirm the absence of bacteria growth by comparing the colors obtained with the ones of the positive and negative controls, according to methodology adapted from Duarte et al. (2005). The tubes with no bacteria growth were subjected to CFU count in specific media for each bacterial strain Eosin Methylene Blue Agar-Levine for E. coli, Xylose Lysine Decarboxylase agar for Salmonella, and Baird-Parker agar for Staphylococcus aureus. The plates were incubated at 37 ${ }^{\circ} \mathrm{C}$ for 24 hours, in duplicate (APHA, 2001).

A mix of $200 \mathrm{~g}$ of feed and microencapsulated lemon grass essential oil at rate of $120 \mu \mathrm{L} \mathrm{g}^{-1}$ was used to evaluate the stability of the oil activity in the feed during storage. This mix was stirred for homogenization and stored at room temperature in a sanitized aerated environment with no light. The viability of the oil in the feed were analyzed at the first and seventh day of storage.

The stability of the microencapsulated lemon grass essential oil was evaluated by taken $1 \mathrm{~g}$ of the feed with $9 \mathrm{ml}$ of BHI and $12.5 \mu \mathrm{L}$ of each bacterium. The inocula used in the tests were 
prepared in a $0.9 \%$ saline solution, obtaining between $10^{4}$ and $10^{5}$ Colonies Forming Units (CFU) $\mathrm{mL}^{-1}$, with 0.5 in the Marc Farland scale for each bacterium (CLSI, 2015) and incubated it at $37^{\circ} \mathrm{C}$ for 24 hours. The same procedure without microencapsulated lemon grass essential oil in the feed was performed as control for this test. After the incubation period, the CFU was counted according to the recommendations for each bacteria strain (APHA, 2001). The bacterial counts were compared at the first and seventh days of storage, and the reduction in bacteria counts were calculated at each analysis. The tests were performed in triplicates for each replication.

The data obtained were subjected to analysis of variance (ANOVA) and F test to compare the results found with each oil concentration and controls.

\section{RESULTS AND DISCUSSION}

The MIC and MBC of the microencapsulated lemon grass essential oil for the evaluated bacteria was $80 \mu \mathrm{L} \mathrm{mL} \mathrm{m}^{-1}$. A previous study (AZEVEDO et al., 2016) found a MIC of $80 \mu \mathrm{L} \mathrm{mL} \mathrm{m}^{-1}$ for this oil before its microencapsulation for these same bacteria, but the MBC was not detected. These data show that the microencapsulation of the essential oil improved its effectiveness, since the MBC was detected with the microencapsulated oil. This indicates that this technique is efficient to conserve and prevent oxidation of the oils, and improve their activity.

Other studies also showed the beneficial effect of microencapsulation of oils on the microbial activity. The microencapsulation of lemon grass essential oil by simple conservation technique had no effect on the MIC against $E$. coli and $S$. aureus bacteria (LEIMAN, 2008). Studies evaluating other essential oils showed similar effects with oil without microencapsulation and improvements in the oil antimicrobial activity (SILVA et al., 2011; SOUZA et al., 2015), which varied between essential oils and techniques used for microencapsulation.

The microencapsulated lemon grass essential oil concentration of $120 \mu \mathrm{L} \mathrm{mL}^{-}$

${ }^{1}$ was defined as ideal for use in studies evaluating the addition essential oil to feeds. This concentration is above the in vitro MIC and MBC found, since organic components may affect the activity of the essential oils (PESAVENTO et al., 2015).

According to the analysis of the antiseptic activity of the microencapsulated lemon grass essential oil depending on the contact time, the $S$. aureus bacterium requires a shorter contact time (15 minutes) for bactericidal effect, followed by E. coli (30 minutes) and $S$. enterica (60 minutes).

The difference in the contact time required for each bacterium denotes the action of the essential oils on the cell walls of Gram-positive and Gramnegative bacteria. The primary action of the essential oils is the destabilization of the cell wall (CALO et al, 2015). Thus, the chemical reactions that the oil causes in the cell wall of the bacteria may have different characteristics and the effect of the oil may cause cell death at different times and be dependent on the oil concentration.

The organic matter in the feed can also affect the MIC and MBC results. Different groups of organic matter, feed components, and chemical characteristics of the oils (PESAVENTO et al., 2015), such as $\mathrm{pH}$ and hydrophobicity (NEGI et al., 2012), can hinder the dissolution the 
essential oils in the feed and affect their action.

The CFU $(\log x+1)$ of the bacteria evaluated in the feed with oil was counted and compared to the control bacterial growth without oil in the first and seventh day of feed storage. The oil was active in the first day, inhibiting microbial growth and reducing the CFU in 2.98 for $S$. aureus, 2.82 for E. coli, and 2.95 for $S$. enterica, compared to control group $(\mathrm{p}<0.05)$ (Table 1). The oil remained active up to the seventh day, reducing the CFU in 3.08 for $S$. aureus, 3.01 for $E$. coli, and 3.10 for $S$. enterica, compared to the control $(p<0.05) \quad($ Table 1$)$. The bactericidal activity increased with increasing time of the oil in the organic matter, presenting higher reductions of CFU at the seventh than in the first day. However, the difference in the reductions of $\mathrm{CFU}$ at the first and seventh day had no significant differences $(\mathrm{p}>0.05)$ for any strain studied (Table 1). This confirms the stability of the antibacterial activity of the oil under the storage conditions of the present study.

Table 1. Stability of feeds treated with microencapsulated lemon grass essential oil for broiler chickens, at the first and seventh day of storage.

\begin{tabular}{|c|c|c|c|c|c|c|c|c|c|}
\hline \multirow{2}{*}{ Item } & \multicolumn{4}{|c|}{ First day $^{+}$} & \multicolumn{4}{|c|}{ Seventh day $^{+}$} & \multirow{2}{*}{$P^{++}$} \\
\hline & Control & With oil & $\neq$ & p-value & Control & With oil & $\neq$ & p-value & \\
\hline S. aureus & $7.13^{\mathrm{a}}$ & $4.15^{b}$ & 2.98 & 0.009 & $7.21^{\mathrm{a}}$ & $4.13^{b}$ & 3.08 & 0.008 & 0,10 \\
\hline E. coli & $7.55^{\mathrm{a}}$ & $4.73^{b}$ & 2.82 & 0.002 & $7.14^{\mathrm{a}}$ & $4.13^{b}$ & 3.01 & 0.000 & 0,19 \\
\hline S. enterica & $7.45^{\mathrm{a}}$ & $4.50^{\mathrm{b}}$ & 2.95 & 0.004 & $7.46^{\mathrm{a}}$ & $4.36^{\mathrm{b}}$ & 3.10 & 0.011 & 0,15 \\
\hline
\end{tabular}

Despite the lack of studies on time of stability of essential oils in the presence of organic matter, according to the results found in the present study, the microencapsulated lemon grass essential oil remains with antibacterial activity up to seven days of feed storage, when homogenized with feeds. The stability of essential oils added to feeds must be evaluated for longer periods. However, the period of 7 days is recommended to improve animal performance and feed efficiency, and the multiphase feeding program (ROSTAGNO et al., 2011) may enable the use of the microencapsulated lemon grass essential oil as an additive in feeds, when they are prepared for using within periods shorter than seven days.
These results are promising for the inclusion of the microencapsulated lemon grass essential oil as an antimicrobial additive in feeds in poultry farming.

The addition of microencapsulated lemon grass essential oil at concentration of $80 \mu \mathrm{L} \mathrm{mL} \mathrm{m}^{-1}$ to feeds used in poultry farming has antibacterial activity for Escherichia coli, Staphylococcus aureus, and Salmonella enterica bacteria.

The microencapsulated lemon grass essential oil adding to feeds used in poultry farming improves the stability of the feeds up to seven days of storage. 


\section{ACKNOWLEDGEMENTS}

We would like to thank everyone who contributed to this study with financial support from the agencies FAPEMIG (Fundação de Amparo à Pesquisa do Estado de Minas Gerais, Brazil), CNPq (Conselho Nacional de Desenvolvimento Científico e Tecnológico, Brazil), CAPES (Coordenação de Aperfeiçoamento de Pessoal de Nivel Superior, Brazil), and Pró-Reitoria de Pesquisa of UFMG (PRPq/UFMG).

\section{REFERENCES}

AZEVEDO, I,L.; ALMEIDA, A.C. de; MARTINS, E.R.; NOGUEIRA, W.C.L.; FARIA FILHO, D.E. de; OLIVEIRA, S.P.; PRATES, J.P.B.; SOUZA, C.N. de. Eficácia in vitro do óleo essencial de capim-limão (Cymbopogon flexuosus STEUD. WATS.) frente a bactérias entéricas de origem avícola. Acta Veterinaria Brasilica, v.10, n.1, p.25-31, 2016.

\section{AMERICAN PUBLIC HEALTH ASSOCIATION - APHA.}

Compendium of methods for the microbiological examination of foods. Washington: APHA, 2001.

BRASIL. Ministério da Agricultura, Pecuária e Abastecimento. Instrução Normativa SDA $n^{\circ} 62$ de 26 de agosto de 2003. Métodos analíticos oficiais para análises microbiológicas para controle de produtos de origem animal e água. Diário Oficial da República Federativa do Brasil, Brasília, DF, 18 de setembro de 2003. 265p.

CALO, J.R.; CRANDALL, P.G.; O'BRYAN, C.A.;RICKE, S.C. Essential oils as antimicrobials in food systems: a review. Food Control, v.54, p. 111119, 2015.
CLINICAL LABORATORY

STANDAR INSTITUTE - CLSL. Methods for dilution antimicrobial susceptibility tests for bacteria that grow aerobically; Approved standard -, M07- A9. Wayne, PA: Clinical and Laboratory Standards Institute; 2015.

DUARTE, M.C.T.; FIGUEIRA, G.M; SARTORATTO, A.; REHDER, V.L.; DELARMELINA, C. Anti-Candida activity of Brazilian medicinal plants. Journal of Ethnopharmacology, v.97, n.2, p.305-311, 2005.

GONZALES, E.; MELLO, H.H. DE C.; CAFÉ, M.B. Uso de antibióticos promotores de Crescimento na alimentação e produção animal. Revista UFG, v.13, n.13, p. 48-52, 2012.

LEIMANN, F, V. Microencapsulação do óleo essencial de capim limão utilizado no processo de coacervação. 2008. 115p. Dissertação (Mestrado em Engenharia Química)- Centro Tecnológico, Universidade Federal de Santa Catarina, Florianópolis. 2001.

NEGI, P.S. Plant extracts for the control of bacterial growth: Efficacy, stability and safety issues for food application.

International Journal of Food Microbiology, v.156, p.7-17, 2012

PESAVENTO, G.; CALONICO, C.; BILIA, A.R.; BARNABEI, M.; CALESIN, F.; ADDONA, R.; MENCARELLI, L.; CARMAGNIN, L.; Di MARTINO, M.C.; Lo NOSTRO, A. Antibacterial activity of Oregano, Rosmarinus and Thymus essential oils against Staphylococcus aureus and Listeria monocytogenes in beef meatballs. Food Control, v.54, p.188199, 2015. 
ROSTAGNO, H.S.; ALBINO, L.F.T.;

DONZELE, J.L.; GOMES, P.C.;

OLIVEIRA, R.F. DE; LOPES, D.C.;

FERREIRA, A.S.; BARRETO, S.L. DE

T.; EUCLIDES, R.F. Tabelas

brasileiras para aves e suínos:

composição de alimentos e exigências

nutricionais. 3.ed. Viçosa: Universidade

Federal de Viçosa, 2011. 252p.

SILVA, M.A. da; PESSOTTI, B.M. de

S.; ZANINI, S.F.; COLNAGO, G.L.;

NUNES, L. de C.; RODRIGUES,

M.R.A.; FERREIRA, L. Óleo essencial

de aroeira-vermelha como aditivo na

ração de frangos de corte. Ciência

Rural, v.41, n.4, p.676-681, 2011.

SOUZA, D, S.; ALMEIDA, A.C.;

ANDRADE, V.A.; MARCELO, N.A.;

AZEVEDO, I.L.; MARTINS, E.R.;

FIGUEIREDO, L.S. Atividade

antimicrobiana do óleo essencial de

Lippia origanoides e Lippia rotundifolia

frente a bactérias isoladas de aves.

Arquivo Brasileiro de Medicina

Veterinária e Zootecnia, Belo

Horizonte, v. 67, n. 3, p. 940-944, 2015.

Data de recebimento: 08/05/2017

Data de aprovação: 14/11/2017 